\title{
PENGEMBANGAN MODUL FISIKA BERBASIS MASALAH PADA MATERI TERMODINAMIKA UNTUK MENINGKATKAN KETERAMPILAN GENERIK SAINS SISWA KELAS XI SMA/MA
}

\author{
Farahita Maya Canty Dewi ${ }^{1}$, Widha Sunarno ${ }^{2}$ dan Sarwanto ${ }^{3}$ \\ ${ }^{1}$ Magister Pendidikan Sains, Fakultas Keguruan dan Ilmu Pendidikan, Universitas Sebelas Maret \\ Surakarta, 57126, Indonesia \\ farahita57@gmail.com \\ 2 Magister Pendidikan Sains, Fakultas Keguruan dan Ilmu Pendidikan, Universitas Sebelas Maret \\ Surakarta, 57126, Indonesia \\ widhasunarno@staff.uns.ac.id \\ ${ }^{3}$ Magister Pendidikan Sains, Fakultas Keguruan dan Ilmu Pendidikan, Universitas Sebelas Maret \\ Surakarta, 57126, Indonesia \\ sarwanto@fkip.uns.ac.id
}

\begin{abstract}
Abstrak
Pembelajaran di sekolah belum maksimal menggunakan pembelajaran berbasis masalah oleh sebab itu modul fisika berbasis masalah pada materi termodinamika perlu dikembangkan untuk meningkatkan keterampilan generik sains siswa yang masih rendah. Penelitian ini bertujuan: (1) mendeskripsikan karakteristik modul fisika berbasis masalah untuk meningkatkan keterampilan generik sains siswa pada materi termodinamika; (2) mengembangkan modul pembelajaran fisika berbasis masalah yang layak untuk meningkatkan keterampilan generik sains siswa pada materi termodinamika; 3) mengetahui peningkatkan keterampilan generik sains siswa setelah mengikuti pembelajaran menggunakan modul fisika berbasis masalah hasil pengembangan. Penelitian ini merupakan penelitian Research and Development yang dikemukakan oleh Thiagarajan (1974) dengan model 4D. Uji coba menggunkan one group pretest-posttest design. Modul disusun dengan tahapan berbasis masalah yaitu merumuskan masalah, merumuskan hipotesis, mengumpulkan data, menguji hipotesis, dan merumuskan kesimpulan. Analisis data pada tahap define adalah analisis data deskriptif, pada tahap design menggunakan analisis kualitatif, pada tahap develop untuk data validasi modul menggunakan nilai cut off dan data keterampilan generik sains dianalisis menggunakan uji $\mathrm{t}$ berpasangan dan dihitung dengan $N$-Gain ternormalisasi, dan pada tahap disseminate menggunakan analisis data deskriptif. Hasil penelitian ini: (1) karakteristik modul yang dikembangkan memuat tahapan berbasis masalah pada setiap kegiatan belajar dengan komponen indikator keterampilan generik sains; (2) modul dikategorikan layak berdasarkan ahli materi, media, bahasa, guru fisika, dan peer review yang ditunjukkan dengan nilai rata-rata 85,23 lebih besar dari nilai minimum kelayakan 84,25. Serta didukung dengan respon dari siswa dengan kategori baik dan hasil disseminate yang mengkategorikan modul sangat baik; (3) keterampilan generik sains siswa setelah menggunakan modul fisika berbasis masalah pada materi termodinamika mengalami peningkatan dalam kategori sedang dengan $N$ Gain sebesar 0,62.
\end{abstract}

Kata Kunci: Modul Fisika, Pembelajaran Berbasis Masalah, Keterampilan Generik Sains.

\section{Pendahuluan}

Pembelajaran yang diharapkan adalah pembelajaran yang inovatif, relevan dengan kebutuhan dan peran aktif siswa dalam pembelajaran. Hal ini sesuai dengan Jufri (2013: 42) sistem penyelenggaraan pembelajaran dan penilaian hasil belajar siswa harus berubah dari pola teacher centered ke pola student centered. Hakikat sains atau fisika merupakan ilmu pengetahuan tentang gejala alam yang dituangkan berupa fakta, konsep, prinsip dan hukum yang teruji kebenarannya dan melalui suatu rangkaian kegiatan dalam metode ilmiah (Suparno, 2007). 
Berdasarkan hasil observasi di SMA Negeri 2 Surakarta, diketahui bahwa prestasi belajar siswa pada mata pelajaran fisika masih rendah dibandingkan dengan mata pelajaran lainnya. Permasalahan-permasalahan yang dihadapi dalam proses pembelajaran antara lain: (1) masih sulitnya penentuan model-model pembelajaran yang harus digunakan untuk meningkatkan kompetensi siswa karena masih terbatasnya pemahaman guru terhadap modelmodel pembelajaran inovatif; (2) keterbatasan tersedianya bahan ajar yang inovatif bagi siswa; (3) proses pembelajaran yang masih terpusat pada guru yang dikarenakan kurangnya motivasi belajar pada siswa saat proses pembelajaran sehingga siswa kurang kreatif dan mandiri; (4) sampai saat ini, keterampilan generik sains siswa masih sangat rendah, hal ini terlihat bahwa siswa masih kesulitan dalam menggunakan bahasa simbolik sebagai sarana komunikasi, menyatakan besaran kuantitatif, kemampuan abstraksi yaitu menggambarkan peristiwa yang abstrak ke dalam bentuk kehidupan nyata dan berfikir logika; dan (5) siswa masih kesulitan dalam menentukan cara menyelesaikan masalah ketika diberi persoalan dalam proses pembelajaran fisika di kelas.

Pembuatan bahan ajar yang inovatif merupakan salah satu solusinya. Bahan ajar yang dirasa mampu membantu peserta didik dan guru dalam proses belajar adalah modul. Modul dijadikan pilihan karena memiliki beberapa kelebihan diantaranya: 1) sebagai sumber belajar yang dimiliki siswa sepenuhnya sehingga siswa dapat mempelajari modul di sekolah maupun di rumah; 2) mengaktifkan indera penglihatan, pendengaran, dan gerakan siswa; 3) mengurangi pembelajaran yang berpusat pada guru; dan 4) modul memberikan feddback yang banyak dan segera karena pada modul terdapat kunci jawaban sehingga siswa dengan segera dapat mengetahui taraf hasil belajarnya. Pengembangan modul dapat menjawab atau memecahkan masalah ataupun kesulitan dalam belajar (Depdiknas, 2008).

Penerapan model pembelajaran berbasis masalah dimaksudkan untuk meningkatkan partisipasi dan prestasi belajar siswa karena siswa menjadi terlatih dalam merumuskan dan menyelesaikan masalah yang mereka temui dalam kehidupan sehari-hari. Model pembelajaran berbasis masalah merupakan suatu model pembelajaran yang didasarkan pada banyaknya permasalahan yang membutuhkan penyelidikan autentik yakni penyelidikan yang membutuhkan penyelesaian nyata dari permasalahan yang nyata.

Fisika merupakan salah satu bentuk ilmu pengetahuan alam yang dapat dipandang sebagai disiplin kerja (Brotosiswoyo, 2001). Peranan tersebut diaplikasikan dalam kerangka tubuh fisika itu sendiri yang mampu menghasilkan berbagai keterampilan, khususnya keterampilan generik sains untuk bekal saat bekerja dalam berbagai profesi yang luas di masyarakat. Pembelajaran fisika harus dilakukan sesuai dengan hakikatnya sebagai cabang dari sains. Dengan demikian pembelajaran fisika tidak hanya menitikberatkan pada produk saja tetapi juga pada proses dan sikap ilmiah.

Berdasarkan dari pemikiran pada latar belakang yang telah dipaparkan, dapat dikatakan bahwa bahan ajar merupakan bagian dari sumber belajar. Penyiapan dan penggunaan bahan ajar berbasis masalah diharapkan dapat mengkonstruk pengetahuan siswa serta melatih siswa dalam memecahkan masalah, pada akhirnya secara akumulatif keterampilan generik sains dan hasil belajar siswa dapat meningkat. Dari uraian di atas, maka dilakukan penelitian pengembangan modul pembelajaran fisika berbasis masalah pada materi termodinamika untuk meningkatkan keterampilan generik sains siswa. Penelitian ini bertujuan untuk: (1) mendeskripsikan karakteristik modul fisika berbasis masalah untuk meningkatkan keterampilan generik sains siswa pada materi termodinamika; (2) mengembangkan modul pembelajaran fisika berbasis masalah yang layak untuk meningkatkan keterampilan generik sains siswa pada materi termodinamika; dan 3) mengetahui peningkatkan keterampilan generik sains siswa setelah mengikuti pembelajaran menggunakan modul fisika berbasis masalah hasil pengembangan. 


\section{Metode Penelitian}

Penelitian ini menggunakan metode penelitian dan pengembangan (research and development). Pada penelitian pengembangan ini produk yang dihasilkan adalah modul fisika berbasis masalah pada materi termodinamika untuk meningkatkan keterampilan generik sains siswa kelas XI SMA/MA. Model penelitian yang digunakan merupakan hasil adaptasi model 4-D dari Thiagarajan (1974), langkah-langkahnya: define, design, develop, dan disseminate.

\section{Tahap Define}

Pada tahap define, metode pengumpulan data yang digunakan adalah angket. Teknik angket dilakukan menggunakan instrumen angket kebutuhan guru dan siswa. Data yang diperoleh dari angket dianalisis menggunakan analisis deskriptif yang kemudian diperoleh skor rata-rata yang dikonversi menjadi persentase.

\section{Tahap Design}

Pada tahap design, data yang diperoleh dianalisis menggunakan analisis data kualitatif model Spradley (dalam Sugiyono, 2009). Desain eksperimen yang digunakan adalah one group pretest and posttest, sehingga penelitian hanya melibatkan sekelompok subjek yang diberi pretest sebelum dikenai perlakuan, dan posttest setelah dikenai perlakuan untuk diketahui hasil akibat perlakuan tersebut.

\section{Tahap Develop}

Data yang diperoleh pada tahap develop adalah data validasi ahli (materi dan media), guru fisika dan peer review, nilai pretest posttest dan angket respon. Teknik analisis data untuk data validasi modul menggunakan nilai cut off dan data keterampilan generik sains siswa dianalisis menggunakan uji $\mathrm{t}$ berpasangan dan dihitung dengan $N$-gain ternormalisasi menggunakan persamaan Meltzer (2002). Angket respon dianalisis menggunakan kategori skala empat menurut teori Mardapi (2004).
Pada tahap disseminate, data yang diperoleh adalah data angket respon guru fisika. Data yang diperoleh dari angket dianalisis menggunakan analisis deskriptif yang kemudian diperoleh skor rata-rata dengan pengkategorian menggunakan skala tiga menurut Azwar (2005).

\section{Hasil Penelitian dan Pembahasan}

\section{Deskripsi Data}

Penelitian dan pengembangan modul fisika berbasis masalah dilakukan dengan menggunakan model4-D yang meliputi: 1) define, 2) design, 3) develop, dan 4) disseminate. Setiap tahapan menunjukkan hasil sebagai berikut:

\section{Tahap Define}

Deskripsi data hasil angket kebutuhan guru dan siswa pada tahap define menunjukkan $100 \%$ siswa membutuhkan media pembelajaran alternatif, $88,89 \%$ siswa merasa keterbatasan dari buku belajar (misal materi dan teknik penjelasan), $77,78 \%$ pembelajaran tidak disajikan masalah, $74,07 \%$ siswa tidak bisa mengungkap fenomena dalam bentuk rumusan, $62,96 \%$ guru kurang mengarahkan siswa untuk menarik kesimpulan setelah melakukan diskusi.

\section{Tahap Design}

Tahap design dilakukan dengan pengumpulan materi yang sesuai dengan KI, KD dan indikator kemudian menyusun pola keterkaitan kegiatan dalam modul dengan sintak pembelajaran berbasis masalah dengan keterampilan generik sains. Pola keterkaitan kegiatan dalam modul dapat dilihat pada Tabel 1 .

\section{Tahap Disseminate}


Tabel 1. Pola Keterkaitan Kegiatan dalam Modul

\begin{tabular}{|c|c|c|c|}
\hline Modul & $\begin{array}{l}\text { Sintaks } \\
\text { Pembela- } \\
\text { jaran }\end{array}$ & $\begin{array}{l}\text { Kegiatan } \\
\text { Siswa }\end{array}$ & $\begin{array}{l}\text { Keteram- } \\
\text { pilan } \\
\text { Generik } \\
\text { sains }\end{array}$ \\
\hline $\begin{array}{l}\text { Menyajikan } \\
\text { permasalahan } \\
\text { berupa } \\
\text { fenomena } \\
\text { alam untuk } \\
\text { membangun } \\
\text { keterampilan } \\
\text { generik sains } \\
\text { siswa dalam } \\
\text { memecahkan } \\
\text { permasalahan }\end{array}$ & $\begin{array}{l}\text { Identifikasi } \\
\text { Masalah }\end{array}$ & $\begin{array}{l}\text { Mengidentifikasi } \\
\text { permasalahan } \\
\text { yang disajikan } \\
\text { dalam modul dan } \\
\text { mendiskusikan- } \\
\text { nya dengan teman } \\
\text { sejawat/kelom- } \\
\text { pok }\end{array}$ & $\begin{array}{l}\text { Kerangka } \\
\text { logika taat } \\
\text { asas dan } \\
\text { konsistensil } \\
\text { ogis }\end{array}$ \\
\hline $\begin{array}{l}\text { Menyediakan } \\
\text { LKS untuk } \\
\text { Siswa } \\
\text { menuliskan } \\
\text { permasalahan } \\
\text { /rumusan } \\
\text { masalah yang } \\
\text { akan } \\
\text { dipecahkan. }\end{array}$ & $\begin{array}{l}\text { Merumuskan } \\
\text { masalah }\end{array}$ & $\begin{array}{l}\text { Siswa } \\
\text { menentukan } \\
\text { prioritas } \\
\text { masalah dan } \\
\text { menggunakan } \\
\text { pengetahuannya } \\
\text { untuk } \\
\text { menganalisis } \\
\text { masalah }\end{array}$ & $\begin{array}{l}\text { Kerangka } \\
\text { logika taat } \\
\text { asas, } \\
\text { konsistensil } \\
\text { ogis dan } \\
\text { hukum } \\
\text { sebab } \\
\text { akibat }\end{array}$ \\
\hline $\begin{array}{l}\text { Menyediakan } \\
\text { kolom pada } \\
\text { LKS untuk } \\
\text { siswa } \\
\text { menuliskan } \\
\text { hipotesis dari } \\
\text { permasalahan }\end{array}$ & $\begin{array}{l}\text { Merumuskan } \\
\text { hipotesis }\end{array}$ & $\begin{array}{l}\text { Siswa } \\
\text { menentukan } \\
\text { dugaan } \\
\text { sementara dari } \\
\text { masalah yang } \\
\text { ingin } \\
\text { diselesaikan }\end{array}$ & $\begin{array}{l}\text { Hukum } \\
\text { sebab } \\
\text { akibat }\end{array}$ \\
\hline $\begin{array}{l}\text { Terdapat } \\
\text { petunjuk } \\
\text { tentang } \\
\text { langkah- } \\
\text { langkah } \\
\text { eksperimen } \\
\text { dan Tabel } \\
\text { hasil kegiatan } \\
\text { eksperimen }\end{array}$ & $\begin{array}{l}\text { Mengum- } \\
\text { pulkan data }\end{array}$ & $\begin{array}{l}\text { Siswa } \\
\text { melakukan } \\
\text { eksperimen atau } \\
\text { pengukuran }\end{array}$ & $\begin{array}{l}\text { Pengamatan } \\
\text { langsung, } \\
\text { pengamatan } \\
\text { tidak } \\
\text { langsung, } \\
\text { kesadaran } \\
\text { tentang skala, } \\
\text { dan bahasa } \\
\text { simbolik } \\
\end{array}$ \\
\hline $\begin{array}{l}\text { Menyediakan } \\
\text { pertanyaan } \\
\text { pada LKS } \\
\text { yang } \\
\text { berkaitan } \\
\text { dengan data } \\
\text { yang telah } \\
\text { diperoleh } \\
\end{array}$ & $\begin{array}{l}\text { Menguji } \\
\text { hipotesis }\end{array}$ & $\begin{array}{l}\text { Siswa } \\
\text { merumuskan } \\
\text { kesimpulan } \\
\text { dengan } \\
\text { menghubungkan } \\
\text { dengan masalah } \\
\text { yang dikaji }\end{array}$ & $\begin{array}{l}\text { Konsistensi } \\
\text { logis dan } \\
\text { pemodelan } \\
\text { matematika }\end{array}$ \\
\hline $\begin{array}{l}\text { Menyarankan } \\
\text { siswa untuk } \\
\text { membanding } \\
\text { kan hasil } \\
\text { yang } \\
\text { diperoleh } \\
\text { dengan } \\
\text { hipotesis } \\
\text { yang telah } \\
\text { siswa ajukan }\end{array}$ & $\begin{array}{l}\text { Merumus- } \\
\text { kan } \\
\text { rekomenda-si } \\
\text { pemecahan } \\
\text { masalah }\end{array}$ & $\begin{array}{l}\text { Siswa memilih } \\
\text { alternatif } \\
\text { penyelesaian } \\
\text { yang mungkin } \\
\text { untuk dilakukan } \\
\text { dan } \\
\text { menuliskannya } \\
\text { di dalam LKS }\end{array}$ & $\begin{array}{l}\text { Hukum } \\
\text { sebab } \\
\text { akibat, } \\
\text { pemodelan } \\
\text { matematika } \\
\text { dan } \\
\text { memba- } \\
\text { ngun } \\
\text { konsep }\end{array}$ \\
\hline
\end{tabular}

\section{Tahap Develop}

Tahap develop merupakan tahap pengembangan. Tahapan ini terdiri dari tahapan validasi, uji coba terbatas (kelas kecil), dan uji coba pemakaian (kelas besar).

\section{Validasi}

Pada tahap validasi, modul divalidasi oleh satu orang dosen ahli materi, satu orang dosen ahli media, satu orang ahli bahasa, dua orang guru fisika, dan dua orang teman sejawat (peer review). Hasil validasi dari para validator dapat dilihat pada Tabel 2.

Tabel 2. Hasil Validasi Modul

\begin{tabular}{lll}
\hline Validator & Jumlah Skor & Kriteria \\
\hline Ahli Materi & 118 & Sangat Baik \\
Ahli Media & 117 & Sangat Baik \\
Ahli Bahasa & 59 & Baik \\
Guru Praktikan & 196,5 & Sangat Baik \\
Peer Review & 169 & Sangat Baik \\
\hline
\end{tabular}

Berdasarkan Tabel 2 diketahui bahwa hasil validasi modul pada kelayakan materi diperoleh skor 118 dari skor maksimum 140 dengan kategori sangat baik, hasil validasi modul pada komponen media diperoleh skor 117 dari skor maksimum 120 dengan kategori sangat baik, hasil validasi modul pada kelayakan bahasa diperoleh skor 59 dari skor maksimum 75 dengan kategori baik, hasil validasi modul oleh guru fisika diperoleh skor 196,5 dari skor maksimum 220 dengan kategori sangat baik, dan hasil validasi modul oleh teman sejawat diperoleh skor 169 dari skor maksimum 200 dengan kategori sangat baik. Saran dan komentar dari beberapa para validator antara lain:

a. Ahli Materi

Komponen yang dinilai dalam validasi materi yaitu meliputi kesesuaian materi dengan Kompetensi Inti (KI) dan Kompetensi Dasar (KD); kedalaman materi sesuai dengan taraf berpikir siswa; keakuratan materi; hubungan konsep dengan kehidupan sehari-hari; fenomena yang disajikan sesuai dengan kenyataan dalam kehidupan sehari-hari, memberikan pengalaman langsung, dan mengajak siswa aktif dalam kegiatan pembelajaran. Berdasarkan hasil validasi diperoleh persentase keidealan untuk validasi materi sebesar $84,28 \%$ dengan kriteria sangat baik. Saran dan komentar dari validator ahli materi dapat dilihat pada Tabel 3.

Tabel 3. Saran dan Komentar Ahli Materi

\begin{tabular}{ll}
\hline No. & Saran dan Komentar \\
\hline 1 & Urutan materi kurang pas \\
2 & $\begin{array}{l}\text { Pada prasyarat konsep ditambahkan persamaan gas } \\
\text { ideal }\end{array}$ \\
\hline
\end{tabular}




\begin{tabular}{ll}
\hline 3 & Fenomena yang dimunculkan dihubungkan dengan \\
materi & \\
Ada gambar yang memiliki keterangan dan ada \\
gambar yang tidak memiliki keterangan disarankan \\
setiap gambar memilki keterangan gambar
\end{tabular}

\section{b. Ahli Media}

Komponen yang dinilai dalam validasi media yaitu meliputi penampilan unsur tata letak pada kulit muka, belakang, dan punggung secara harmonis, serta konsisten; kesesuaian ukuran modul dengan standar ISO (A4, A5, dan B5); penggunaan variasi huruf (bold, italic, capital,) tidak berlebihan; tidak menggunakan terlalu banyak jenis huruf; Ilustrasi/gambar sesuai dengan penempatannya pada setiap materi; penyajian keseluruhan ilustrasi serasi; dan ketepatan tata letak huruf dan gambar pada modul. Berdasarkan hasil validasi diperoleh persentase keidealan untuk validasi media sebesar 97,5\% dengan kriteria sangat baik. Saran dan komentar dari validator ahli media dapat dilihat pada Tabel 4 .

Tabel 4. Saran dan Komentar Ahli Media

\begin{tabular}{cl}
\hline No. & Saran dan Komentar \\
\hline 1 & $\begin{array}{l}\text { Ada beberapa tulisan pada gambar yang perlu } \\
\text { diperbesar }\end{array}$ \\
2 & $\begin{array}{l}\text { Penulisan warna huruf sebaiknya diganti sama semua } \\
\text { Ada beberapa gambar yang kurang jelas dan belum }\end{array}$ \\
ada sumbernya
\end{tabular}

b. Ahli Bahasa

Komponen yang dinilai dalam validasi bahasa meliputi kesesuaian bahasa dengan kemampuan kognitif siswa SMA; bahasa yang digunakan mudah dipahami; bahasa yang digunakan tidak menimbulkan makna ganda; penggunaan bahasa secara efektif, efisien dan komunikatif; penggunaan ejaan secara benar; kebenaran menggunakan istilah; penggunaan struktur kalimat yang tepat; konsistensi penggunaan istilah dan simbol; pemenggalan kata sesuai dengan aturan pemenggalan kata; ketepatan penggunaan tanda baca; ketepatan penggunaan singkatan kata-kata/akronim; dan ketepatan penggunaan kata serapan. Berdasarkan hasil validasi diperoleh persentase keidealan untuk validasi bahasa sebesar $78,67 \%$ dengan kriteria baik. Saran dan komentar dari validator ahli bahasa dapat dilihat pada Tabel 5.
Tabel 5. Saran dan Komentar Ahli Bahasa

\begin{tabular}{cl}
\hline No. & Saran dan Komentar \\
\hline 1 & Konstitensi dalam penggunaan kata sapaan antara \\
& anda dengan kalian \\
2 & Penulisan bahasa asing dicetak miring \\
3 & Memperbaiki tanda baca dan ejaan yang sesuai EYD \\
\hline
\end{tabular}

\section{c. Guru Praktikan}

Komponen yang dinilai dalam validasi oleh guru praktikan meliputi menggambarkan isi/materi ajar dan mengungkapkan karakter materi; kejelasan tulisan dan gambar; ketepatan tata letak huruf dan gambar pada modul; penggunaan variasi huruf (bold, italic, capital,) tidak berlebihan; ilustrasi/gambar sesuai dengan penempatannya pada setiap materi; kemudahan ilustrasi untuk dipahami; penyajian keseluruhan ilustrasi serasi; petunjuk penggunaan bahan ajar disajikan secara jelas; bahasa yang digunakan menarik perhatian siswa; ilustrasi/gambar sesuai dengan penempatannya pada setiap materi; hubungan konsep dengan kehidupan sehari-hari; mengajak siswa aktif dalam kegiatan pembelajaran; fenomena yang disajikan sesuai dengan kenyataan dalam kehidupan seharihari; keakuratan fakta dan konsep; dan kelengkapan materi sesuai kemampuan peserta didik. Berdasarkan hasil validasi diperoleh persentase keidealan untuk validasi oleh guru praktikan sebesar 89,32\% dengan kriteria sangat baik. Saran dan komentar dari validator guru praktikan dapat dilihat pada Tabel 6 .

Tabel 6. Saran dan Komentar Guru Praktikan

\begin{tabular}{cl}
\hline No. & Saran dan Komentar \\
\hline 1 & Konstitensi dalam penggunaan kata \\
2 & Memperbaiki tanda baca dan ejaan yang sesuai EYD \\
3 & Menambahkan penjelasan untuk mengungkapkan \\
& hubungan antara metabolisme tubuh dengan \\
& termodinamika pada materi, pada pertanyaan, atau \\
& pada soal sehingga siswa lebih memahami materi \\
& termodinamika \\
\hline
\end{tabular}

\section{d. Teman Sejawat (Peer Review)}

Komponen yang dinilai dalam validasi oleh teman sejawat meliputi komponen materi, komponen bahasa, komponen tampilan dan gambar dan komponen penyajian. Berdasarkan hasil validasi diperoleh persentase keidealan untuk validasi oleh teman sejawat sebesar $84,50 \%$ dengan kriteria sangat baik. Saran dan komentar dari validator teman sejawat dapat dilihat pada Tabel 7. 
Tabel 7. Saran dan Komentar Teman sejawat (Peer Review)

\begin{tabular}{cl}
\multicolumn{1}{c}{ Review) } \\
\hline No. & Saran dan Komentar \\
\hline 1 & $\begin{array}{l}\text { Terdapat inkonsistensi dalam penggunaan istilah } \\
\text { kata ganti bagi pembaca }\end{array}$ \\
2 & $\begin{array}{l}\text { KD 1.1 dan 1.2 belum dimunculkan dalam modul } \\
\text { Kurang konsistensi dalam penggunaan kata anda } \\
\text { dan siapa }\end{array}$ \\
4 & $\begin{array}{l}\text { Gambar di dalam modul sebaiknya diberi } \\
\text { keterangan gambar dan sumbernya }\end{array}$ \\
5 & $\begin{array}{l}\text { Memeriksa kembali huruf kapital dan penggunaan } \\
\text { bullet dan numbering }\end{array}$ \\
6 & $\begin{array}{l}\text { Beberapa gambar sebaiknya diperjelas dengan } \\
\text { gambar yang dapat dibaca kemudian berikan } \\
\text { beberapa penjelasan untuk grafik dalam modul }\end{array}$ \\
\hline
\end{tabular}

\section{Uji Coba Modul}

a. Uji coba kelas kecil

Tahap uji kelas kecil dilakukan kepada 10 siswa dari kelas MIA 4 SMAN 2 Surakarta. Pada tahap ini bertujuan untuk mendapatkan penilaian, saran, dan tanggapan dari siswa terhadap modul fisika yang dikembangkan, data yang didapatkan kemudian dirata-rata. Hasil penilaian dari keterbacaan modul diperoleh skor sebesar 12,5 berada pada kategori tinggi dengan persentase keidealan sebesar $83,33 \%$.

b. Uji coba kelas besar

Tahap uji kelas besar dilakukan kepada 26 siswa dari kelas XI MIA 2 SMAN 2 Surakarta. Sebelum modul fisika diimplementasikan dalam pembelajaran, siswa diberi pretest terlebih dahulu, kemudian siswa diberikan soal posttest setelah melakukan pembelajaran menggunakan modul fisika berbasis masalah. Deskripsi data pretest dan posttest disajikan pada Tabel 8.

Tabel 8. Deskripsi Data Keterampilan Generik Sains

\begin{tabular}{lll}
\hline Jenis Tes & Mean & Standar Deviasi \\
\hline Pretest & 44,42 & 8,52 \\
Posttes & 77,50 & 6,96 \\
\hline
\end{tabular}

Hasil pretest dan posttest diuji prasyarat yaitu uji normalitas dan uji homogenitas. Uji prasyarat ini digunakan sebagai dasar untuk uji selanjutnya yang akan menggunakan uji parametrik atau non parametrik. Hasil uji menunjukkan data pretest dan data posttest berdistribusi normal dan homogen. Keputusan uji selanjutnya yaitu digunakan uji parametrik untuk mengetahui peningkatan keterampilan generik sains siswa. Berdasarkan uji tersebut diperoleh kesimpulan bahwa terdapat perbedaan rata-rata keterampilan generik sains siswa sebelum dan sesudah menggunakan modul fisika berbasis masalah. Dari hasil pretest dan posttest kemudian dihitung $\mathrm{N}$-Gain setiap aspek keterampilan generik sains yang ditunjukkan pada Tabel 9.

Tabel 9. Deskripsi Data $N$-Gain setiap Aspek Keterampilan Generik Sains

\begin{tabular}{lll}
\multicolumn{3}{c}{ Keterampilan Generik Sains } \\
\hline No & Aspek & N-Gain \\
\hline 1 & Bahasa simbolik & 0,55 \\
2 & Pemodelan matematika & 0,57 \\
3 & Hukum sebab akibat & 0,52 \\
4 & Konsistensi logis & 0,86 \\
\hline Rata-rata & 0,62 \\
\hline
\end{tabular}

Berdasarkan Tabel 9 aspek bahasa simbolik, pemodelan matematika, hukum sebab akibat dalam kategori sedang sedangkan aspek konsistensi logis dalam kategori tinggi. Peningkatan keterampilan generik sains siswa juga didukung dari proses kegiatan pembelajaran di kelas. Keterlaksanaan sintak pembelajaran berbasis masalah berdasarkan hasil persentase keterlaksanaan sintak pembelajaran siswa yang dinilai oleh dua orang observer diperoleh berdasarkan aktivitas siswa pada pertemuan I sebesar 70,96 dan 71,15 dengan rata-rata keseluruhan 71,05. Pada pertemuan II sebesar $\mathbf{8 7 , 8 8}$ dan $\mathbf{8 9 , 4 2}$ dengan rata-rata keseluruhan sebesar 88,65. Adapun rata-rata nilai keterlaksanaan sintak pembelajaran dari dua pertemuan di atas yaitu sebesar 79,85.

Angket respon siswa diberikan setelah siswa selesai melaksanaan posttest. Angket respon siswa terdiri dari 4 aspek yaitu perhatian, keterkaitan, keyakinan, dan kepuasan. Data angket menunjukan nilai rata-rata 80,62.

\section{Tahap Disseminate}

Pada tahap penyebaran, modul fisika berbasis masalah pada materi termodinamika disebarkan ke 6 sekolah dengan 10 orang guru fisika SMA/MA di Kota Surakarta. Penyebaran dilakukan pada guru fisika di SMA Negeri 4 Surakarta, SMA Negeri 5 Surakarta, SMA Negeri 6 Surakarta, SMA Negeri 7 Surakarta, SMA Batik 2 Surakarta, dan SMA Muhamadiyah 2 Surakarta. Setelah diberikan modul fisika berbasis masalah pada 
materi termodinamika, kemudian diberikan angket untuk mengetahui respon guru terhadap modul yang telah dikembangkan. Respon guru fisika terhadap modul fisika berbasis masalah disajikan pada Tabel 10.

\begin{tabular}{llll}
\multicolumn{4}{c}{ Tabel 10. Respon Guru Fisika Terhadap Modul } \\
\hline No & Guru Fisika & Skor & Kategori \\
\hline 1 & Guru I & 44 & Sangat Baik \\
2 & Guru II & 42 & Baik \\
3 & Guru III & 44 & Sangat Baik \\
4 & Guru IV & 41 & Baik \\
5 & Guru V & 46 & Sangat Baik \\
6 & Guru VI & 40 & Baik \\
7 & Guru VII & 48 & Sangat Baik \\
8 & Guru VIII & 48 & Sangat Baik \\
9 & Guru IX & 45 & Sangat Baik \\
10 & Guru x & 48 & Sangat Baik \\
\hline \multicolumn{2}{l}{ Rata-rata skor } & 44,6 & Sangat Baik \\
\hline
\end{tabular}

\section{Pembahasan \\ Karakteristik Modul Fisika Berbasis Masalah}

Hasil angket pengungkap kebutuhan guru dan siswa, serta observasi aktivitas siswa yang telah dilakukan diperoleh kesimpulan bahwa dalam proses pembelajaran tidak menggunakan modul dan sebagian besar siswa mengalami kesulitan dalam memahami materi termodinamika. Oleh karena itu, guru dan siswa setuju bila dikembangkan modul yang dapat meningkatkan keterampilan generik sains siswa. Hal ini sesuai dengan pendapat Prastowo (2013) bahwa modul sebagai bahan ajar yang mampu meningkatkan kemampuan siswa untuk belajar mandiri dan modul juga dapat menjelaskan materi pembelajaran dengan baik dan mudah dipahami oleh siswa.

Penyusunan modul fisika mengadaptasi dari format Depdiknas (2008) yang terdiri dari tiga bagian utama, meliputi pendahuluan, isi, dan penutup. Bagian-bagian tersebut kemudian dijabarkan menjadi beberapa komponen sehingga dihasilkan desain modul. Desain awal modul lalu menjadi draf modul dengan karakteristik sebagai berikut:

Pada bagian pendahuluan modul disesuaikan dengan data analisis kebutuhan. Karakteristik modul berbasis masalah terdapat pada bagian pendahuluan modul. Tahapan berbasis masalah yang digunakan mengadaptasi langkah pembelajaran berbasis masalah menurut Hamruni (2012) yaitu merumuskan masalah, merumuskan hipotesis, mengumpulkan data, menguji hipotesis, dan merumuskan rekomendasi pemecahan masalah. Tahapan model pembelajaran berbasis masalah dimunculkan di dalam modul, hal tersebut dimaksudkan untuk mempermudah penyusunan modul sesuai dengan karakteristik yang digunakan. Selain itu, pada bagian pendahuluan juga ditampilkan prasyarat konsep yaitu syarat kemampuan awal siswa sebelum mempelajari modul dan terdapat petunjuk penggunaan modul baik petunjuk untuk siswa maupun guru. Akhirnya ditampilkan tujuan akhir yang diharapkan dapat dicapai oleh siswa setelah melakukan kegiatan dan mempelajari modul.

Penyusunan isi modul meliputi rincian dan urutan penyajian materi yang harus sesuai dengan desain awal yang dibuat. Untuk bagian isi terdapat dua kegiatan belajar yang telah disusun berdasarkan sub materi yang akan dipelajari siswa. Setiap kegiatan belajar berisi tujuan pembelajaran yang diharapkan dapat dicapai siswa setelah mempelajari kegiatan belajar tersebut. Pada setiap kegiatan belajar terdapat penyajian permasalahan, percobaan sederhana dengan langkah-langkah berdasarkan masalah yang dilakukan siswa secara berkelompok. Menurut Susanti (2013) melalui diskusi kelompok, mahasiswa akan dapat merumuskan beberapa solusi alternatif dan mengevaluasi manakah solusi terbaik terhadap masalah yang dipecahkan.

Pada bagian isi terdapat uraian materi, contoh soal, penyajian tokoh fisika, konsepkonsep penting dalam setiap uraian materi, kilas balik dan soal evaluasi. Siswa dapat melihat tingkat penguasaan materi untuk setiap Kegiatan belajar dengan mencocokkan jawabannya dengan kunci yang telah disediakan. Setelah itu, siswa dapat melihat ada bagian tindak lanjut. Jika nilai yang diperoleh sudah di atas 70, maka siswa diperbolehkan melanjutkan pada kegiatan belajar berikutnya.

Pada bagian penutup terdapat soal evaluasi untuk mengukur hasil belajar siswa setelah mempelajari modul pada materi termodinamika. Selain itu, terdapat juga glosarium, kunci jawaban, dan daftar pustaka. 
Menurut Andriani (2011) dengan menggunakan modul hasil pengembangan berdasarkan pembelajaran berbasis masalah menunjukkan bahwa lebih dari $90 \%$ siswa mencapai kriteria ketuntasan minimal (KKM).

\section{Kelayakan Modul Fisika Berbasis Masalah}

Setelah draf modul fisika disusun, kemudian modul dikonsultasikan kepada dosen pembimbing I dan dosen pembimbing II. Setelah mendapatkan masukan dan perbaikan dari dosen pembimbing I dan II, kemudian draf modul tersebut dilakukan validasi. Validasi modul dilakukan terhadap satu orang ahli materi, satu orang ahli media, satu orang ahli bahasa, dua orang guru fisika, dan dua orang peer review. Validasi ini bertujuan untuk mengetahui kelayakan isi materi, media, bahasa, penyajian dan kegrafikan dari modul yang dikembangkan. Hal ini sesuai dengan penelitian yang dilakukan oleh Lidy (2013) yang menunjukkan bahwa modul yang telah teruji kelayakannya mampu meningkatkan pemahaman siswa dan layak digunakan dalam pembelajaran fisika.

\begin{tabular}{llr}
\multicolumn{2}{c}{ Berdasarkan hasil } & validasi \\
menunjukkan bahwa modul yang
\end{tabular} dikembangkan pada kelayakan materi memperoleh kategori sangat baik, kelayakan media memperoleh kategori sangat baik, kelayakan bahasa memperoleh kategori baik, kelayakan guru fisika memperoleh kategori sangat baik, dan kelayakan oleh peer review memperoleh kategori sangat baik. Validasi guru fisika dan peer review dilakukan karena seperti yang dinyatakan oleh Dick dan Carey (2005: 282) bahwa akan sangat membantu bila draf produk pengajaran diberi masukan oleh kolega atau rekan kerja yang sudah mengenal baik target sasaran siswa.

Berdasarkan hasil validasi kemudian dilakukan perhitungan cutt off yang menunjukkan nilai rata-rata sebesar 85,23 lebih besar dari nilai minimum kelayakan 84,25 sehingga modul dikategorikan layak digunakan dalam pembelajaran. Menurut Purwadarminto (1989) menyatakan kelayakan adalah kondisi atau keadaan sudah pantas. Kelayakan diukur dengan pemenuhan kriteria modul.
Uji coba kelas kecil dilakukan dengan tujuan untuk melihat keterbacaan modul fisika berbasis masalah pada materi temodinamika sebelum diujicobakan kelas besar. Daryanto (2013) menjelaskan bahwa uji coba kelas kecil digunakan untuk mengumpulkan informasi yang dapat digunakan sebagai bahan untuk memperbaiki produk dalam revisi berikutnya. Sampel uji coba kelas kecil terdiri dari 10 siswa. Siswa mengerjakan LKS yang ada di dalam modul dan mengerjakan uji kompetensi. Setelah itu siswa mengisi angket keterbacaan modul fisika berbasis masalah. Dari 10 siswa menunjukan keterbacaan modul fisika yang dikembangkan memiliki kategori tinggi dengan persentase keidealan sebesar 83,33\%. Setelah diuji coba kelas kecil kepada 10 orang siswa, terdapat saran untuk modul fisika berbasis masalah yang dikembangkan. Menurut Daryanto (2013) hasil uji kelas kecil dijadikan dasar untuk merevisi modul sebelum uji skala besar. Setelah itu siswa mengisi angket keterbacaan modul fisika berbasis masalah yang dikembangkan pada kategori tinggi.

Modul fisika berbasis masalah pada materi termodinamika disebarkan kepada 6 sekolah SMA/MA di Kota Surakarta. Penyebaran dilakukan pada guru fisika SMA Negeri 4 Surakarta, SMA Negeri 5 Surakarta, SMA Negeri 6 Surakarta, SMA Negeri 7 Surakarta, SMA Muhamadiyah 2 Surakarta, dan SMA Batik 2 Surakarta.

Penyebaran dilakukan kepada SMA/MA yang memiliki karakteristik sama dengan sekolah tempat penelitian. Setelah diberikan modul fisika berbasis masalah pada materi termodinamika, kemudian diberikan angket untuk mengetahui respon guru terhadap modul yang telah dikembangkan. Respon guru fisika terhadap modul fisika berbasis masalah pada materi termodinamika masuk dalam kategori sangat baik. Hal ini juga sejalan dengan Nawawi (2015) bahwa respon guru yang sangat baik menjadi tanda bahwa modul yang dikembangkan dapat diimplementasikan dalam pembelajaran di kelas. 


\section{Peningkatan Keterampilan Generik Sains}

Sampel uji coba kelas besar adalah siswa kelas XI MIA 2 di SMAN 2 Surakarta. Sebelum siswa diberikan modul fisika berbasis masalah pada materi termodinamika, dilakukan pretest terlebih dahulu kepada 26 orang siswa. Hasil pretest menunjukkan bahwa keterampilan generik sains siswa rendah. Hal ini mendukung penelitian Liliasari (2009) diperoleh hasil bahwa pada siswa SMA keterampilan generik (pemodelan matematik dan bahasa simbolik) masih menunjukkan pencapaian rendah.

Setelah dilakukan pretest, siswa diberikan pembelajaran menggunakan modul fisika berbasis masalah pada materi termodinamika. Pertemuan pertama dalam pembelajaran menggunakan modul sesuai dengan RPP yang telah disusun sebelumnya.

Kegiatan belajar diawali dengan penyampaian topik, tujuan pembelajaran, hasil belajar yang diharapkan dapat dicapai oleh siswa, menjelaskan pentingnya topik dan kegiatan belajar dalam rangka memberikan motivasi belajar siswa. Setelah itu, guru membagi siswa menjadi 4 kelompok secara heterogen. Satu kelompok terdiri dari 4 orang siswa. Menurut Sudjana (1989), bekerja dalam kelompok dapat meningkatkan cara berfikir siswa sehingga dapat memecahkan suatu permasalahan dengan baik dan lancar. Sedangkan menurut Daryanto (2010) belajar berkelompok sangat cocok untuk belajar aspek kognitif tingkat tinggi, meningkatkan kemampuan kerja sama, meningkatkan keterampilan berkomunikasi, dan mengembangkan aspek afektif.

$\begin{array}{crrr}\text { Guru } & \text { membimbing } & \text { siswa saat } \\ \text { melakukan } & \text { pengamatan } & \text { bersama }\end{array}$ kelompoknya. Setelah selesai melakukan pengamatan, masing-masing kelompoknya mengikuti arahan guru secara tertib menganalisis data hasil percobaan untuk menemukan konsep termodinamika. Setelah itu masing-masing kelompok menyusun hasil diskusi kemudian mempersiapkan presentasi kelompok. Saat memberikan penjelasan mengenai hasil diskusinya, kelompok lainnya menanggapi dengan cara bergantian menjelaskan hasil diskusinya. Hal ini sejalan dengan pendapat Eugenia (2009) terkait pengembangan keterampilan generik bahwa siswa dapat berubah dari pelajar pasif menjadi pelajar aktif dengan penerapan diskusi informasi sehingga siswa dapat berbagi ide dan pemikiran dalam proses pembelajaran.

Setelah semua kelompok mempresentasikan hasilnya, kemudian guru mengambil poin-poin penting mengenai konsep termodinamika. Setelah itu membimbing siswa untuk menyimpulkan materi yang telah dipelajari dan mengklarifikasi serta memberikan informasi yang sebenarnya mengenai termodinamika.

Pertemuan kedua sama halnya pada pertemuan pertama, kegiatan belajar diawali dengan penyampaian topik, tujuan pembelajaran, hasil belajar yang diharapkan yang harus dicapai siswa. Secara keseluruhan alur pada kegiatan belajar kedua sama dengan kegiatan belajar pertama.

Hasil pretest dan posttest kemudian dihitung nilai $N$-Gain setiap aspek keterampilan generik sains dan rata-rata keempat keterampilan generik sains. Nilai $\mathrm{N}$ Gain setiap aspek menunjukkan keterampilan generik sains meningkat. Rata-rata peningkatan keterampilan generik sains pada kategori sedang dengan peningkatan paling besar yaitu pada aspek konsistensi logis dengan kategori peningkatan tinggi. Hal ini sama dengan hasil penelitian Gunawan (2013) yang menunjukkan nilai rata-rata $N$-Gain keterampilan generik pada kategori sedang, namun pada penelitian Gunawan peningkatan $N$-Gain paling tinggi yaitu pada aspek membangun konsep.

Hasil pretest dan posttest diuji prasyarat yaitu uji normalitas dan homogenitas. Uji prasyarat ini digunakan sebagai dasar untuk uji selanjutnya yaitu uji parametrik atau non parametrik. Hasil uji menunjukkan data pretest dan posttest berdistribusi normal dan homogen. Keputusan uji selanjutnya yaitu uji parametrik untuk mengetahui peningkatan keterampilan generik sains siswa. Uji parametrik yang digunakan untuk mengetahui peningkatan keterampilan generik sains siswa yaitu uji $t$ untuk dua 
kelompok berpasangan pada data pretest dan posttest. Dapat disimpulkan bahwa terdapat perbedaan rata-rata keterampilan generik sains siswa sebelum menggunakan modul dan sesudah menggunakan modul. Hal ini menunjukkan bahwa ada pengaruh signifikan modul fisika berbasis masalah terhadap peningkatan keterampilan generik sains siswa. Hal ini sejalan dengan penelitian Rusnayati dan Prima (2011) yaitu adanya pengaruh signifikan model pembelajaran berbasis masalah terhadap peningkatan penguasaan konsep dan keterampilan proses sains. Hal ini juga sejalan dengan penelitian Gunawan (2008) dalam penelitiannya menemukan bahwa terdapat korelasi linier antara keterampilan generik sains dengan penguasaan konsep fisika.

Peningkatan keterampilan generik sains juga didukung dari proses kegiatan pembelajaran di kelas. Keterlaksanaan sintak pembelajaran berbasis masalah dapat dilihat berdasarkan integrasi berbasis masalah dengan keterampilan generik sains siswa yang terdapat pada modul fisika. Hasilnya dipersentase berdasarkan pengamatan oleh dua orang observer terhadap aktivitas siswa di kelas. Berdasarkan hasil persentase keterlaksanaan sintak pembelajaran siswa diperoleh berdasarkan aktivitas siswa pada pertemuan I sebesar 70,96 dan 71,15 dengan rata-rata keseluruhan 71,05. Pada pertemuan II sebesar 87,88 dan 89,42 dengan rata-rata keseluruhan sebesar 88,65. Adapun rata-rata nilai keterlaksanaan sintak pembelajaran dari dua pertemuan di atas yaitu sebesar 79,85 dengan kategori tinggi. Proses pembelajaran yang berjalan baik sangat berpengaruh terhadap keterampilan generik sains siswa. Hasil penelitian Wahyudi dan Nurhayati (2014) menguatkan bahwa keterampilan generik sains dapat meningkat setelah melalui proses pembelajaran berbasis masalah. Hal ini juga sesuai dengan penelitian Susanti (2013) praktikum berbasis masalah dapat meningkatkan keterampilan generik sains.

Modul fisika berbasis masalah pada materi termodinamika disebarkan kepada 6 sekolah SMA/MA di Kota Surakarta. Penyebaran dilakukan pada guru fisika SMA Negeri 4
Surakarta, SMA Negeri 5 Surakarta, SMA Negeri 6 Surakarta, SMA Negeri 7 Surakarta, SMA Muhamadiyah 2 Surakarta, dan SMA Batik 2 Surakarta.

Penyebaran dilakukan kepada SMA/MA yang memiliki karakteristik sama dengan sekolah tempat penelitian. Setelah diberikan modul fisika berbasis masalah pada materi termodinamika, kemudian diberikan angket untuk mengetahui respon guru terhadap modul yang telah dikembangkan. Respon guru fisika terhadap modul fisika berbasis masalah pada materi termodinamika masuk kategori sangat baik. Menurut Winarni et al. (2014) hasil respon guru pada kategori sangat baik menunjukkan bahwa modul dikategorikan layak untuk digunakan sebagai salah satu media pembelajaran.

\section{Kesimpulan dan Rekomendasi}

\section{Kesimpulan}

Karakteristik modul fisika dikembangkan dengan berbasis masalah pada materi termodinamika untuk meningkatkan keterampilan generik sains siswa. Tahapan yang dimunculkan sebagai kerangka dalam modul meliputi merumuskan masalah, merumuskan hipotesis, mengumpulkan data, menguji hipotesis dan merumuskan kesimpulan. Selain tahapan berbasis masalah sebagai konten yang dikembangkan, modul juga dilengkapi dengan komponen keterampilan generik sains yang terdapat pada tahapan-tahapan berbasis masalah. Keterampilan generik sains meliputi bahasa simbolik, pemodelan matematika, hukum sebab akibat, dan konsistensi logis. Model pengembangan modul fisika berbasis masalah pada materi termodinamika menggunakan model 4-D yang meliputi define, design, develop dan disseminate. Berdasarkan angket pengungkap kebutuhan guru fisika dan siswa pada tahap define, disusunlah draf modul (design). Tahap selanjutnya adalah develop, draf modul dikonsultasikan kepada dosen pembimbing I dan dosen pembimbing II. Selanjutnya divalidasi oleh ahli materi, ahli media, ahli bahasa, guru fisika SMA, dan teman sejawat. Setelah itu diuji coba skala 
kecil kepada 10 orang siswa, kemudian diimplementasian di kelas. Tahap terakhir yaitu tahap disseminate, modul fisika berbasis masalah pada materi termodinamika disebarkan ke 6 sekolah di Surakarta dengan jumlah total guru 10 orang.

Modul dikategorikan layak karena telah melalui beberapa uji kelayakan. Berdasarkan uji validasi oleh ahli materi diperoleh hasil dengan kategori sangat baik dengan persentase $84,29 \%$, uji validasi oleh ahli materi diperoleh hasil dengan kategori sangat baik dengan persentase $97,50 \%$, uji validasi oleh ahli bahasa diperoleh hasil dengan kategori baik dengan persentase $78,67 \%$, uji validasi oleh guru fisika SMA diperoleh hasil dengan kategori sangat baik dengan persentase $89,32 \%$, uji validasi oleh teman sejawat diperoleh hasil dengan kategori sangat baik dengan persentase $84,50 \%$. Modul juga mendapatkan respon baik dari siswa. Kelayakan juga didukung oleh hasil disseminate yang mengkategorikan modul tergolong sangat baik.

Modul fisika berbasis masalah pada materi termodinamika dapat meningkatkan keterampilan generik sains siswa. Peningkatan setiap aspek keterampilan generik sains dilihat dari pretest dan posttest yang dihitung menggunakan gain score ternormalisasi yang mendapatkan skor 0,62 dengan kategori sedang. Keterampilan generik sains yang diteliti meliputi bahasa simbolik, pemodelan matematika, hukum sebab akibat dan konsistensi logis. Keterampilan generik sains yang memiliki $N$-Gain paling tinggi yaitu aspek konsistensi logis, kedua pemodelan matematika, ketiga bahasa simbolik dan yang keempat hukum sebab akibat.

\section{Rekomendasi}

Berdasarkan hasil penelitian maka diajukan beberapa rekomendasi sebagai berikut:

(1) Guru seharusnya memperhatikan karakteristik model pembelajaran yang digunakan sebelum diterapkan dalam pembelajaran fisika di kelas. Guru hendaknya mulai untuk mengembangkan modul untuk pembelajaran fisika di kelas agar sesuai dengan karakteristik siswa. Pengembangan modul membuat siswa juga akan semakin mudah dalam menerima konsep fisika yang mereka pelajari, dengan tidak hanya mengandalkan LKS dan buku paket yang tidak sesuai dengan karakter pembelajaran siswa di kelas; (2) Penelitian ini dapat digunakan sebagai acuan untuk mengembangkan penelitian sejenis, terutama penelitian pengembangan modul pembelajaran fisika. Peneliti dapat mengembangkan modul dengan karaktetistik dan materi yang berbeda. Peneliti harus memahami tentang karakteristik model pembelajaran yang akan digunakan. Siswa sebagai sampel penelitian hendaknya diberikan pemahaman yang jelas tentang pembelajaran berbasis masalah. Untuk memperoleh keterampilan generik yang baik, siswa hendaknya dilatih dengan mengerjakan soalsoal yang dapat mengukur keterampilan generik sains. Pada tahap penyebaran, peneliti dapat menyebarkan produk hasil pengembangan tidak hanya pada 6 sekolah pada satu kabupaten.

\section{Daftar Pustaka}

Andriani, F. (2011). Pengembangan Modul Pembelajaran Kimia untuk Kelas XISemester III Program Kejuruan Teknik Mekanik Otomotif dengan Pendekatan Pembelajaran Berbasis Masalah (PBL). Abstrak. Malang: PPs Universitas Negeri Malang.

Azwar, S. (2005). Penyusunan Skala Psikologi. Yogyakarta: Pustaka Pelajar.

Brotosiswoyo, B.S. (2001). Hakikat

Pembelajaran Fisika di Perguruan Tinggi. Jakarta: Proyek Pengembangan Universitas Terbuka, Direktorat Jendral Pendidikan Tinggi, Depdiknas.

Depdiknas. (2008). Pengembangan Bahan Ajar. Sosialisasi KTSP 2008. Di download pada tanggal 29 Januari 2014 jam 20.00 WIB dari:http://dc218.4shared.com/download/vj 4M9KIo/5_PENGEMBANGAN_BAHAN _AJAR.rar?tsid=20120227-061731a8f2e 27 . 
Daryanto. (2010). Belajar dan Mengajar. Bandung: Yrama Widya.

. (2013). Menyusun Modul. Yogyakarta: Gava Media.

Dick, W. Carey, L. \& Carey, J. O. (2005). The Systematic Design of Instruction. Boston: Omegatype Typography, Incoperation.

Eugenia. (2009). Developing Student Teachers' Generic Skills Through Computer Supported Learning Environments. Jurnal of Instructional Media, 36 (4) 1-9.

Gunawan. (2008). Model Pembelajaran Berbasis Multimedia Interaktif untuk Meningkatkan Penguasaan Konsep Calon Guru pada Materi Elastisitas. Jurnal Penelitian Pendidikan IPA, 2(1) 11-21. . (2013). Model Virtual Laboratory

Fisika Modern untuk Meningkatkan Keterampilan Generik Sains Calon Guru. Jurnal Pendidikan dan Pembelajaran, 2(01).

Hamruni. (2012). Strategi Pembelajaran. Yogyakarta: Insan Madani.

Jufri, W. (2013). Belajar dan Pembelajaran

Sains. Bandung: Rineka Cipta.

Lidy, A., \& Setyadi, E. (2013). Studi Tentang Pengembangan Modul Fisika pada Pokok Bahasan Listrik Dinamis Berbasis Domain Pengetahuan Sains untuk Mengoptimalkan Mind-on Siswa. Jurnal Radiasi Universitas Muhamadiyah Purworejo, 3(01).

Liliasari. (2009). Scientific concepts and generic science skills relationship in the $21 \mathrm{st}$ century science education. Makalah pada Seminar Internasional I SPS UPI. Bandung: SPs UPI.

Mardapi, D. (2004). Penyusunan Tes Hasil Belajar. Yogyakarta: Pasca UNY.

Meltzer. (2002). The Relationship Between Mathematics Preparation and Conceptual Learning Gains in Phisics: a Possible "Hidden Variable" in Diagnostic Pretest Score. Lowa: lowa State University. American Journal, 70(12) 1259-1268.

Nawawi, S. (2015). Pengembangan Modul Berbasis Challenge Based Learning pada
Materi Lingkungan untuk Meningkatkan Kemampuan Berfikir Kritis Siswa. Thesis. Universitas Sebelas Maret Surakarta.

Prastowo, A. (2013). Pengembangan Bahan Ajar Tematik. Yogyakarta: DIVA Press.

Purwadarminto. (1989). Kamus Besar Bahasa Indonesia. Jakarta: Balai Pustaka.

Rusnayati, H., \& Prima, E. C. (2011). Penerapan Model Pembelajaran Problem Based Learning dengan Pendekatan Inkuiri untuk Meningkatkan Keterampilan Proses Sains dan Penguasaan Konsep Elastisitas. Prosiding Seminar Nasional Penelitian, Pendidikan dan Penerapan MIPA. Yogyakarta: Universitas Negeri Yogyakarta.

Sudjana, N. (1989). Cara Belajar Siswa Aktif dalam Mengajar. Bandung: Sinar Baru.

Sugiyono. (2009). Metode Statistika. Bandung:

Suparno, P. (2007). Metode Penelitian Pendidikan Fisika. Yogyakarta: Penerbit Universitas Sanata Dharma.

Susanti, R. (2013). Pengaruh Penerapan Pembelajaran Berbasis Masalah pada Praktikum Fotosintesis dan Respirasi untuk Meningkatkan Kemampuan Generik Sains. Seminar Kenaikan Jabatan. Sumatra Selatan: Unsri.

Thiagarajan \& Semmel. (1974). Instructional Development for Training Teacher of Exceptional Children. Bloomington Indiana: Indiana University.

Wahyudi \& Nurhayati. (2014). Penerapan Model PBM dengan Pendekatan Inkuiri Meningkatkan keterampilan Generik Sains Mahasiswa pada Optik Geometri. Prosiding Pertemuan Ilmiah XXVIII HFI Jateng \& DIY, ISSN: 0853-0823.

Winarni, Suparmi, \& Sarwanto. (2014). Pengembangan Modul Berbasis Inkuiri Terbimbing Pada Pokok Bahasan Kalor Untuk SMA/MA Kelas X. Jurnal Inkuiri, 3(01), 29-42. 